\title{
CONSIDERATIONS ON SPATIAL FORMATION AND TRANSFORMATION OF KALOENG HOUSE IN MUKDAHAN PROVINCE, THAILAND \\ ムクダハン地方（タイ）のカロン族住居の空間構成とその変容に関する考察
}

\author{
Chantanee CHIRANTHANUT ${ }^{*}$ and Shuji FUNO** \\ チャンタニーチランタナット, 布野修司
}

\begin{abstract}
This paper aims to clarify the formation and transformation of Kaloeng houses in the Northeastern Province of Thailand. Kaloeng people are classified to be a subgroup of Tai ethnic tribes which is the process of vanishing. There are a few number of Kaloeng villages in Mukdahan and Sakonnakorn province, among which the one in Mukdahan still exists as the origin of the settlements. This paper investigates Kaloeng houses in Mukdahan province, discusses the typology of houses, and reveals the transformation process through the analysis of the relations between types of houses. Based on the analysis of the transformation process, this paper aims to reveal the basic principles of spatial formation of a house.
\end{abstract}

Keywords: Kaloeng, Tai, Tai-Kaloeng, typology of house, transformation process, Ban-Nongnouwn , Mukdahan province カロン, タイ族、タイカロン族、住居類型、変容過程、バン・ノンナウン村、ムクダハン地方

\section{The Objective of the Research}

Most of academic studies of $\mathrm{Tai}^{1}$ houses in Thailand are focused on the main ethnic groups, such as, Tai-lu, Phutai and Phuan, while minor groups are often neglected. These minority groups are in a fragile situation, because they inherent characteristics are rapidly disappearing and their are continuously integrating with the core ethnic group, Thai ${ }^{2}$. Kaloeng people inhabit in a few villages in Mukdahan and Sakonnakorn. The major reason why we selected Ban-Nongnouwn for this study of Kaloeng houses is that it is an outstanding village, more than eighty percent of population of which is Kaloeng people and it still maintains its original appearances at present. The houses in Ban-Nongnouwn have not changed much from when they were first constructed ${ }^{3}$. In contrast, by the impact of new technologies introduced to the rural region, most villages in the Northeastern Region had greatly changed not only their characteristics but also their lifestyles. Almost all the villages have totally changed and lost their original features. The objective of this research is to layout the formation of and to outline the characteristics of Kaloeng houses.

This paper classifies the various types of Kaloeng houses in Mukdahan province based on the field survey of Ban-Nongnouwn and discusses the transformation process through the analysis of the correlations between various house types.

\section{Outline of Kaloeng}

\section{2-1 Tai and Thai}

During the first millennium A.D., before the emergence of formal states governed by Tai-speaking leaders, the people lived in scattered villages, which finally gathered to be a group, so called 'Muang', or principalities.
Each Muang was governed by a Chao, or lord, who ruled by virtue of personal qualities and a network of patron-client relationships. The constituent villages of a Muang was often banded together to defend their lands from more powerful neighboring people, such as the Chinese and Vietnamese.

In the mid 7th century A.D., the Chinese in Tang Dynasty, threatened by powerful western neighbors such as Tibet, sought to secure its southwestern borders by fostering the growth of a friendly state formed by the people they called 'Man' (southern barbarians) in the Yunnan region. $\mathrm{Tai}^{4}$ peoples moved south from China's Yunnan Province into the Indo-Chinese peninsula. They spread across northern Vietnam, Yunnan, Thailand, northern Cambodia, the Shan State of Burma, and as far as Assam across the Indian frontier ${ }^{5}$

In short, the Tai are thought to have originated in southern China's Guangxi region which is an area south of the Yangtze River and are closely related to Thai people who form a majority in Thailand. A number of linguistic scholars classify the core Thai--the Central Thai (or Ayutthaya Thai), the Northeastern Thai (Thai-Lao), the Northern Thai, and the Southern Thai who speak dialects of one of the languages of the Tai language family. Only a small fraction of more than eighty-five percent of the

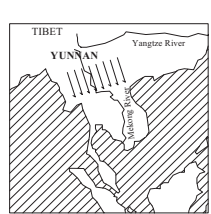

Fig. 1 Tai spreading Fig. 2 Assumed map of migration from Yunnan trace down to Thailand.

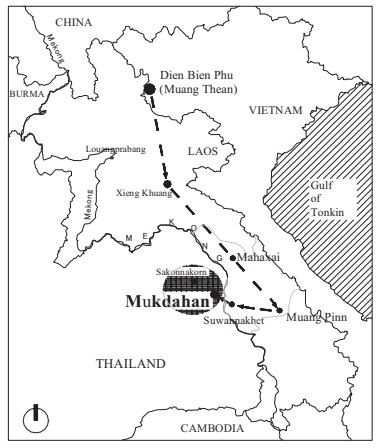

* Ph. D. Candidate, Graduate School of Environmental Science, University of Shiga 滋賀県立大学大学院環境科学 博士後期課程 $\cdot$ 工修 Prefecture

** Prof., Graduate School of Environmental Science, University of Shiga Prefecture, Dr. Eng. 
country's populations speaking a language of the Tai family, constituted the membership of the halfdozen or so ethnic groups outside the core Thai. These groups lived in the North or Northeast. They are closely related to ethnic groups in neighboring countries. It was conventional in the 1980 s to refer to Taispeaking peoples in Thailand as Thai (same pronunciation) with a regional or other qualifier, e.g., central Thai. There are, however, groups in Thailand in the late twentieth century who speak a language of the Tai family but who are not part of the core population ${ }^{6}$.

\section{2-2 Kaloeng}

Kaloeng $^{7}$ or Tai-

Kaloeng is a sub group of the so-called 'minority' or 'tribes'. The same as the Tai, their ancestral place is believed to be around the area of Muang Thaen or

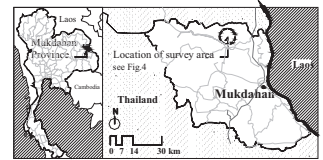

Fig. 3 Mukdahan location

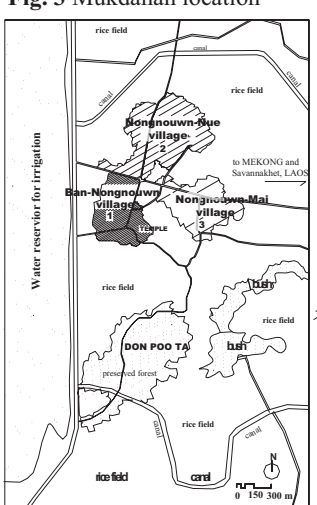

Fig. 4 Village lay out

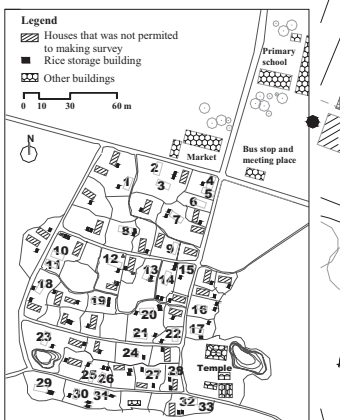

Fig. 5 No. of House surveyed

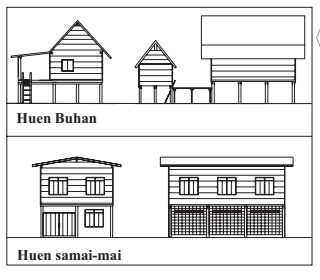

Fig. 6 Characteristic of Huen Buhan and Huen Samai-mai

Dien Bien Phu, in Sipsongchutai state in Vietnam. Here, because of its fertile plain, is a hub for the Tai people including the lowland Lao and other

Tai in the region. Historically, there were tribal conflicts over territory and competition with the more powerful lowland neighbors. Kaloeng people were forced to fight against internal and external Tai groups. In the 17th century A.D., they leaved Muang Thaen and immigrated to the south of Laos; Muang Xieng Khuang, Muang Mahaxai and Muang Pinn in Savannaket. Some of them crossed the Mekong River and finally moved to Mukdahan and Sakonnakorn province in Thailand ${ }^{8}$ (Fig. 2-3). Even though Kaloeng is such a small population but they still maintain their characteristic of their traditional lifestyle and house.

A report by Joachim Schliesinger ${ }^{12)}$ says that the Kaloeng people are classified to an ethnic Tai sub-group of Tai-Kadai. The population of Tai Kaloeng in Thailand is around 8,000. They live mainly in Mukdahan and Sakonnakorn province. According to the National Statistic Office of Thailand in 2000, the average of income of the farmer in Mukdahan province is 3,900 Baht per year.

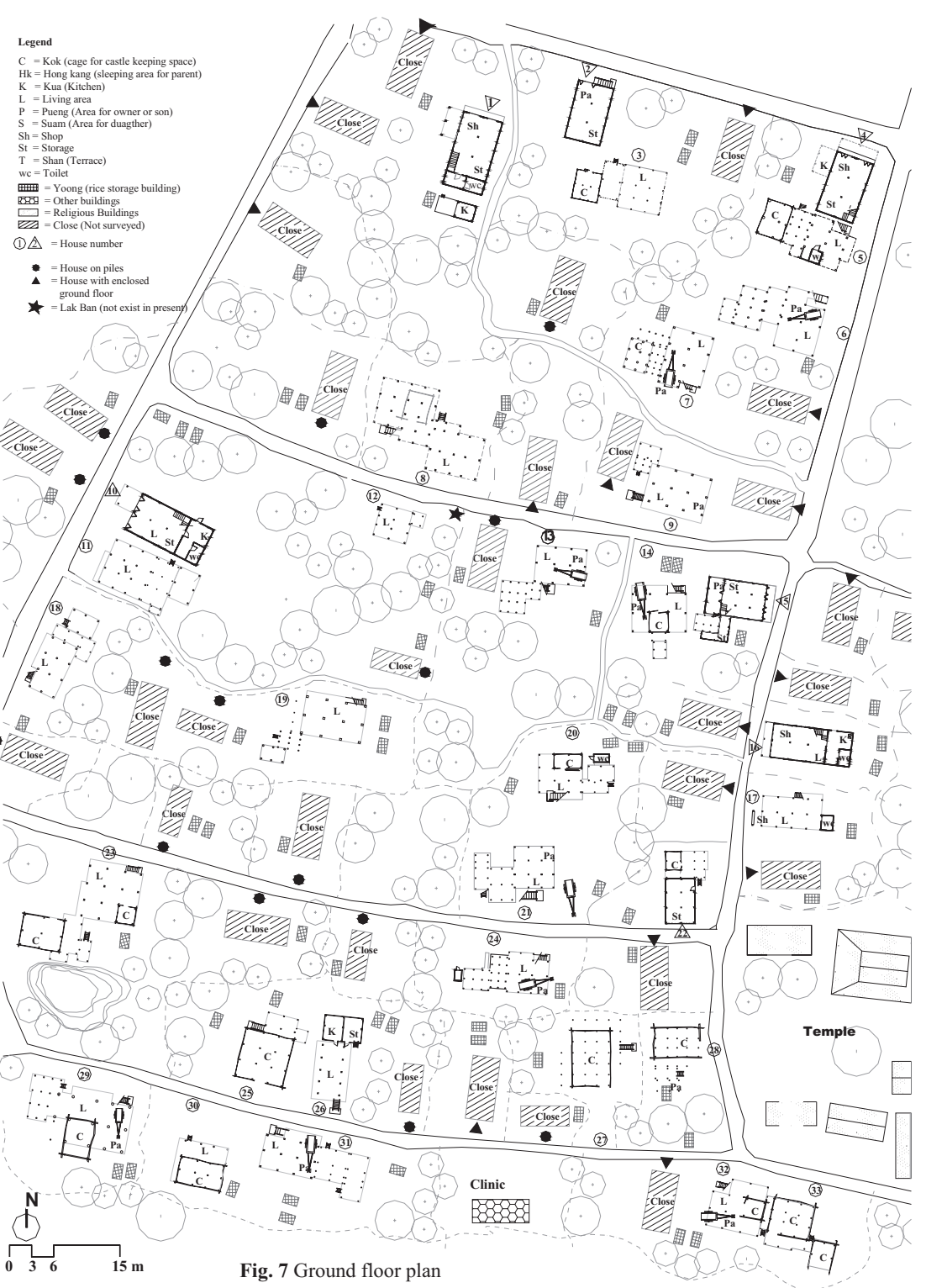

Fig. 7 Ground floor plan

Ban-Nongnouwn's village consists of 3 clusters; Ban-Nongnouwn, BanNongnouwn Mai (Mai means new) and Ban-Nongnouwn Nue (Nue means North). Total population of the village is about 1000, among which about 300 live in Ban-Nongnouwn. Average number of a household is 4-5.

\section{The Formation of Ban-Nongnouwn Village}

At present, among existing villages, Ban-Nongnouwn is an outstanding example as a traditional Kaloeng settlement that still preserves its original features while others were losing them ${ }^{9}$.

The community of Ban-Nongnouwn consists of three social groups; the original one (Ban-Nongnouwn) migrated from Muang Pinn ${ }^{10}$ in Savannaket and the other two extended groups derived from the original group (Fig. 4). One family is thought to possess enough land to house at least two to three generations in the beginning. However, in case where they are no more space for extended families, the later generations had to build their dwelling-units outside the family's site. Most inhabitants who lived in the first original settlement belonged to the first generation. The people who live in the second and the third villages are the descendants of the first 
generation. Through interviews, it became clear that most of the later generations are mixed by marriage with other tribes such as the Laos and the core Thai people.

We focus on the first village where the majority of the residents are Kaloeng. There are 79 households in the first village. We selected 33 households as samples. The 33 sample residents were born and have been living in the village since their birth. The data on aspects such as family structure and the age of buildings are based on personal interview with the residents.

Most of the inhabitants are farmer who believe in Buddhism. They plant rice and palm trees. BanNoungnouwn village is located on a small mound that has slightly slopes to the surrounding plains and rice fields. The water reservoir and a small river are located to the west of the village, which is indispensable for cultivation. There is a market in the north. Wat (temple) is located in the east-west of the village (Fig. 4). In the south of the village (downstream), there is the preserved forest called 'Donpoota' ${ }^{11}$, where everyone in the village can get foods and materials such as mushroom or firewood. Near by Donpoota is Pa-heu or $P a$-cha which is the ancestral burial ground. Expanded villages are located in the north and the east of the original one. The residents conduct different spiritual ceremonies in different locations. The Buddhist temple is the place for Buddhist ceremonies and is used as a community-gathering center while spiritual rituals are conducted at Donpoota.

When the village was first established the residents buried a wooden post called Lak Ban ${ }^{12}$ which is the symbol of commune. This pole is located in the middle of the village and is said to be the key stone to decide the layout of the village.

Dwelling units were basically built separately and scattered in the village site at random (Fig. 5). Walking around the village, we can easily notice that the roof shape of all the houses is gable and more than half the houses are constructed on piles, many of which are 2-3 $\mathrm{m}$. high and some are as low as $1.60 \mathrm{~m}$. However, there are some houses that converted the open space under the floor into multipurpose rooms.

The typical layout of house compound is as follows.

The main building is called 'Tua-huen ${ }^{13}$, and is located in the middle of the site. Residents plant many kinds of trees and vegetables within their compound (Fig.7). There is no significant boundary between house and garden.

The orientation of the house is associated with the directions of sunrise and sunset. The house's longitudinal side is set along the east-west axis, facing the front side to the neighbor. Most dwelling units consist of two buildings; the main one is used for sleeping called 'Tua-huen' and the other is used for cooking called ' $K u a$ '. The kitchen is separated from the main

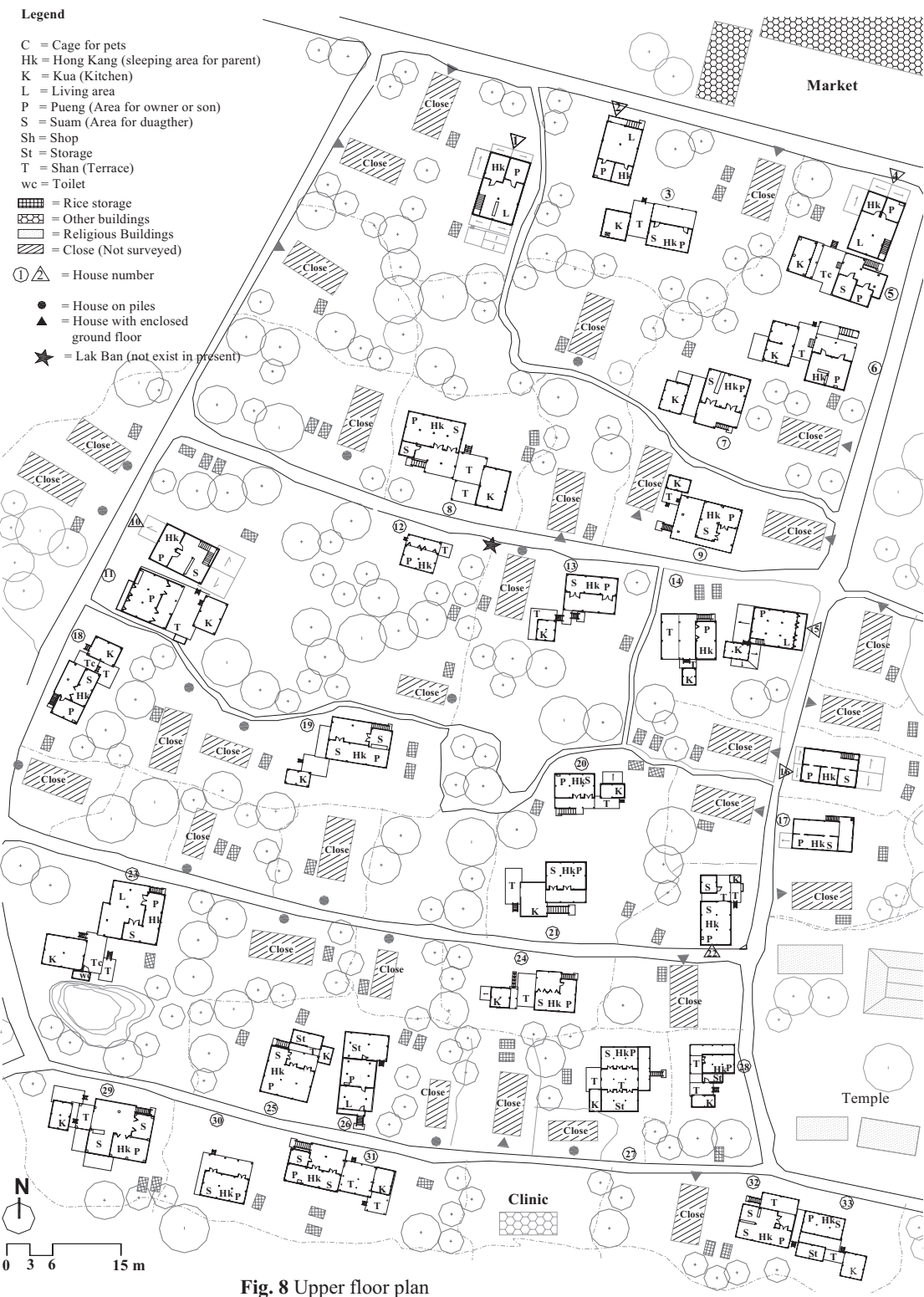

Fig. 8 Upper floor plan

building or is connected to main building through a terrace, so called 'Shan'.

Near the main building is a small free standing timber building called 'Yoong' used for rice storage. Main structure is made of timber and the wall is made of latticed bamboo covered with clay. While the kitchen should be placed in the west or the south, rice storage can be placed in any place except the west. The ground level of rice storage must higher than the kitchen's, because it is the sacred place that is used for stocking rice. It should not be contaminated by waste water from kitchen. In addition, other buildings close to the main building are the toilet ${ }^{14}$ and $K o k$, stable for cattle.

\section{Typology of Houses}

As mentioned above, 33 households are selected for more detailed study to investigate regular patterns in their spatial planning. The floor areas of houses range from $85.61 \mathrm{~m}^{2}$ to $115.19 \mathrm{~m}^{2}$.

More than two-third of the samples are houses with raised floor that are built with timber structure. Houses with raised floor are called 'Huen Buhan $^{15}$ (Huen Noi ${ }^{16}$ and Huen Koei ${ }^{17}$ ).

Seven of the 33 units are completely enclosed by Tai-toon which is made 

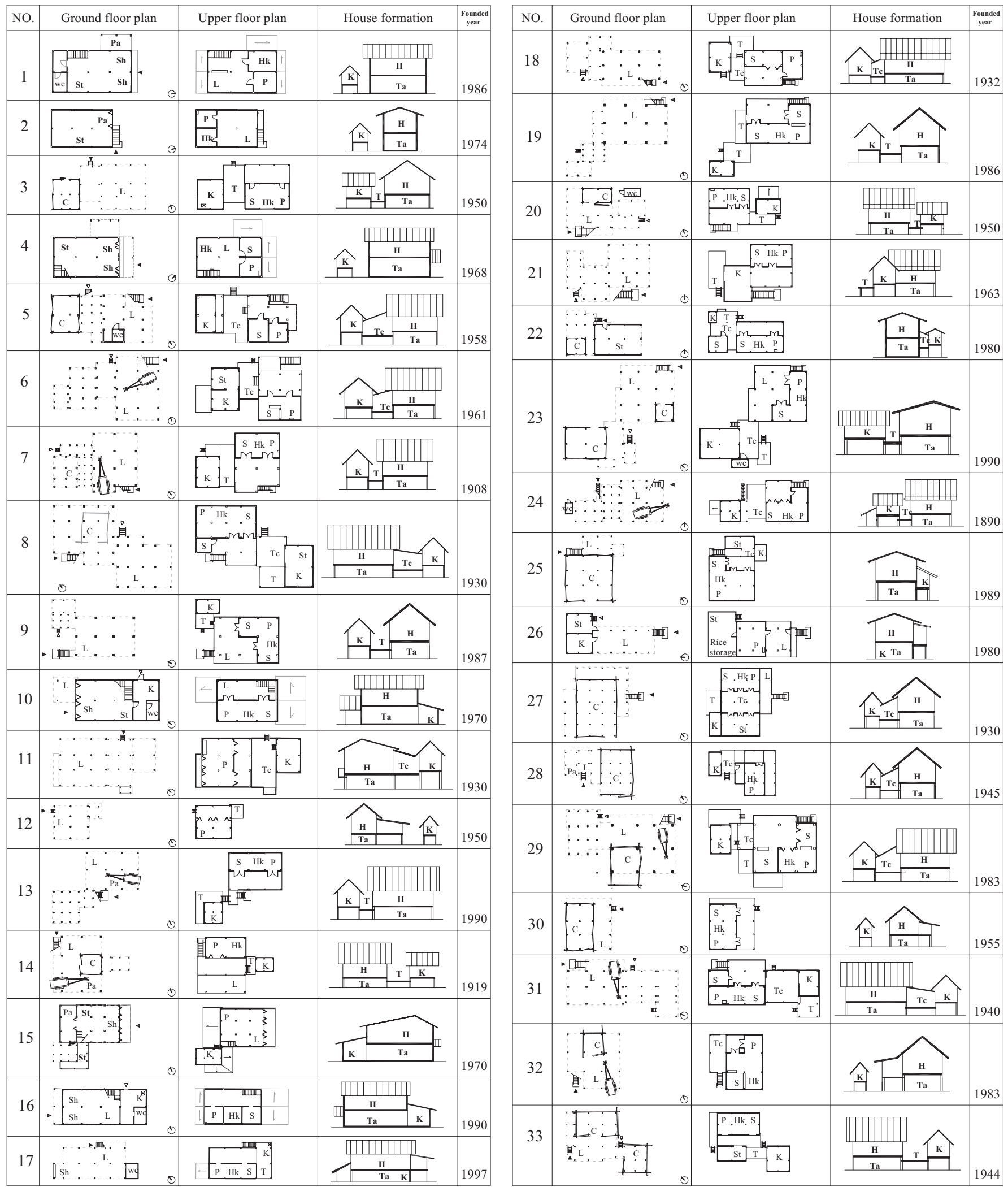

\section{Legend}

$\mathrm{C}=$ Cage for pets

$\mathrm{L}=$ Living area

$\mathrm{Sh}=$ Shop

$\mathrm{H}=$ main house

$\mathrm{P}=$ Peang (for owner or son, sacred place)

$\mathrm{Tc}=$ Terrace with roof

St $=$ Storage

$\mathrm{Hk}=$ Hong kang (sleeping area for parent)

$\mathrm{K}=$ Kitchen

$\mathrm{Pa}=$ Parking

$\mathrm{T}=$ Terrace (Shan)

$\mathrm{S}=$ Suam (Area for duagther)

$\mathrm{wc}=$ Toilet

$\checkmark$ = Main entry

Ta $=$ Tai-toon

$\triangleleft=$ Back entry

Fig.9 List of surveyed houses 


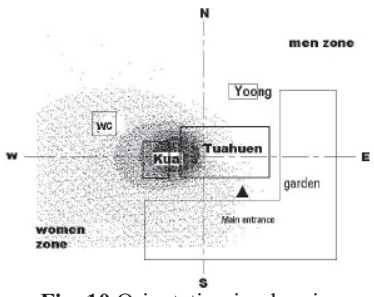

Fig. 10 Orientation in planning
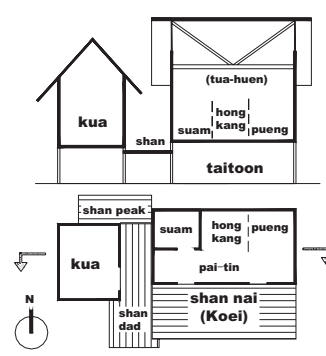

Fig. 11 Typical plan

of reinforced concrete. This type of house is called Huen Samai-mai ${ }^{18}$ (Fig.6).

\section{4-1 Standard type of Dwellings}

Based on the data we received from the residents and our observation, the basic elements of these dwelling units can be outlined as follows.

In terms of spatial formation, orientation play a major role in determining how the dwelling units and compounds are formed (Fig. 10). In BanNongnouwn, the man is believed to be the leader of the family and woman is thought to be the follower of man. The house plan reflects such kind of social hierarchy. The east is believed to be the best direction for men and spirits. Conversely, the west is believed to be the worst direction and position. Living space is separated based on this sense of orientation. The east is used by men and the west is used by women. Functions that are related to men are allocated to the east zone, such as sanctified space called 'Pueng', while the west to the function that are related to women such as the kitchen and daughter's bed room or 'Suam'. To avoid the cross use between man and woman, the space used by woman is placed nearby Suam. To the west of Tua-huen there is Kua (kitchen). On the backside of Kua there is Shan Peak (open space for cleaning dishes or foods). It is believed as a polluted area so it should be placed on the west side of the house and at the level lower than that used by man. More over, the west is believes to be the place for the dead, so the head should not be pointing to the west when people sleep. The house plan is considered to reflect a hierarchy deeply rooted in society.

Principally, the structure system of the house is the traditional post and beam system by interlocking joints. Roof structure using truss is considered to be a pre-fabricated system. After adaptation of processed-timber materials, the construction technique was changed so that even local carpenters could handle. This also enables the owner to apply and create more flexible plan. The foundation and house structure could be separated, due to the development of techniques for materials connections.

At the initial stage, the residents may construct a Huen Noi (Fig.12) a temporary structure, and live in it for 2-3 years. It can be said that Huen Noi is the minimal archetype of the house. It has been considered as the original house. It is the basic house for the new couple to live in. A house normally has two rooms (one is the bed room and the other is the kitchen). This is the

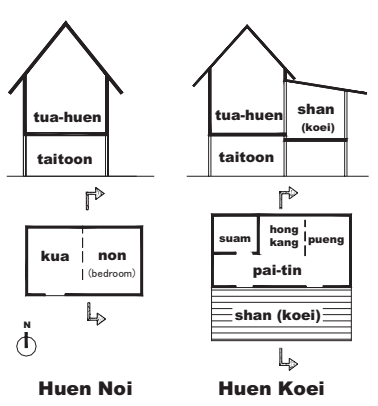

Fig. 12 Huen Buhan minimum space to live in. After inhabitants get married and earn adequate money, the owner might build a permanent house that has more space. Once the permanent house is built, the Huen Noi is converted to be a kitchen.

Fig.11 shows the basic plan and spatial formation clustering around three main parts. This type of house is called 'Huen Koei'.

Basically, this type of dwelling unit is composed of:

a. Main building or Tua-huen (Fig. 11) consists of five main spaces:

- Pueng or the sacred place is located at the east, which is the most important side of the house. It is generally used as a sleeping place by sons at night. Even though there is no physical partition, this space is a very private area where no one except the owner and son can enter because it is believed to be a sacred space. In the past, household shrine for ancestors was placed in one corner of this space, but after they were converted to Buddhist, Buddhist altar was set instead. Nevertheless, in some cases, we often find both of them.

\section{- Hong Kang}

or parent's area is used for sleeping. It is located between Pueng and Suam.

- Suam or daughter's space is a sleeping room for daughters and located in the west. When the main building is not oriented along the east-west axis, this room is put near the kitchen instead. This room is separated from the other spaces by partition instead of curtain.

$$
\text { - Pai-tin }{ }^{19} \text { or }
$$
space in front of sleeping area, is used as multi-purpose area and linking space to Shan-Nai. Here, it is possible for familiar guests to get in.

- Shan or terrace attached to the house along a longitudinal side is an open platform, which is used as

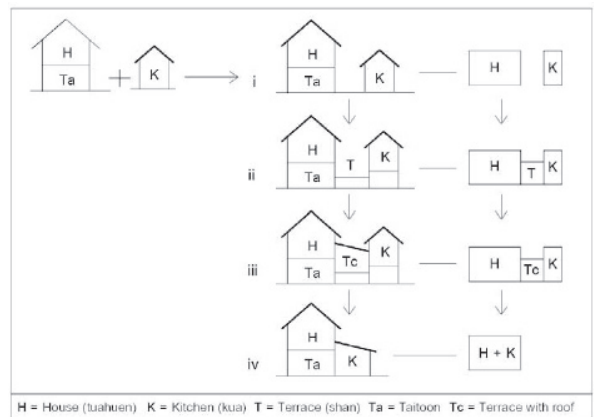

Fig.13 Organization of dwelling units

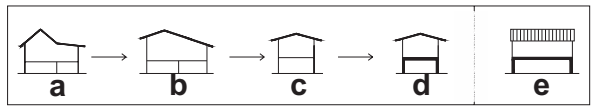

Fig.14 Roof transformation
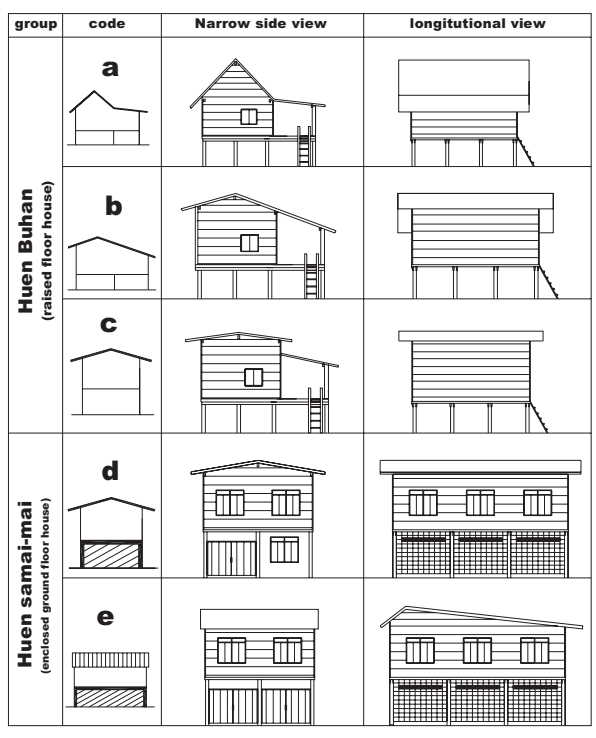

Fig.15 Roof shape

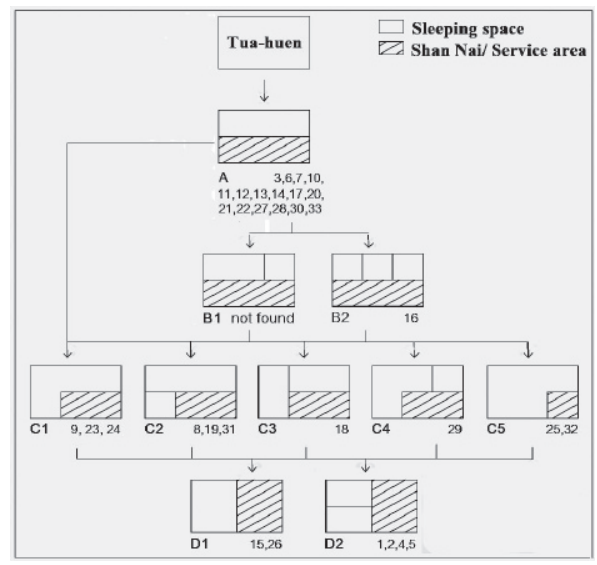

Fig.16 Plan formation 
living area, work area, clothes-drying area, washing agriculture products, and pot planting. It is also a platform to connect each building. A ladder leads to an open platform, which is normally placed at the back side of the main building. There are three main features of Shan;

i) Shan Nai or Koei is a platform with roof adjacent to Pai-tin of the main building. At one corner of Shan, there is a ladder connecting the ground to upstairs.

ii) Shan without roof is called Shan Dad (Dad means sun's ray in Thai), which is mainly used for drying food and cloths, while Shan Nai is used as a place for seating and meeting neighbors. It is always constructed at the level of the floor lower than the main building.

iii) Shan Peak or wetable terrace (Peak means wet in Thai) is used for washing and bathing. This space is useful in the night time (for enjoy the cool of night air) and flooding season (space for temporary storage). It is located near the kitchen.

b. Kua is kitchen. It is separated from Tua-huen and located at the rear of the dwelling unit, close to Suam.

c. Tai-toon or space under the raised floor is used as a living area, work space, preparing space for ceremonies, play ground and agricultural products.

\section{4-2 Organization of Dwelling Units}

All the houses look similar and it seems difficult to categorize them at a glance. The roof looks almost the same and space arrangement also resembles each other. However, it is easy to find two main house types. One is a house on piles made of wood, called Huen Buhan (used to call Huen Noi and Huen Koei for Kaloeng in Ban-Nongnouwn). The other is a house built on grade often with a reinforced concrete basement and flooring, called Huen Samai-mai (Fig. 6).

Residential space is basically composed of living space and service or utility space (cooking and storing). The house plan is arranged based on the relationship between Tua-huen and Kua. They can be classified into the following four types (Fig. 13).

Type i - This minimum organization consists of Tua-huen and Kua which are isolated detached buildings. This is the basic type. It could be assumed that type ii and iii are developed from this standard type. (House No. 1, 2, 4, 12, 30 and 32 total 6 units; $18.18 \%$ )

Type ii - This formation is developed from type i by using Shan Dad as the linkage between Tua-huen and Киа. It serves the inhabitants to escape floods and to sleep in the night time. (House No.3, 7, 9, 13, 14, 19, 20, 21 and 33 total 9 units; $27.27 \%$ )

Type iii - The typical plan looks almost the same as type ii, but Shan or terrace was added to enlarge interior space, and enclosed by walls and roof (House No.6, 11 and 31). Shan is converted from semi-external space to an internal space that could be used in all seasons. The interiorizing of Shan would be done for safety. The majority of houses in the village belong to this type; which occupied $39.39 \%$ of samples. (House No. 5, 6, 8, 11, 18, 22, $23,24,25,27,28,29$ and 31 total 13 units). Toilet and rice storage are sometimes set on the rear of house (House No. 23). Tai-toon tends to be partially enclosed for animal cage, such as storage, toilet, shop, parking, etc. (House No. 5 and 24)
Type iv - This type covers $15.15 \%$ of the samples. This type has no kitchen building as a separate unit, which is different from the other three types above. The kitchen is in the main building (House No.10, 15, 16, 17 and 26).

\section{4-3 Roof Shape}

Gable roof is the common roof form of houses, but there are several variations (Fig.14, and 15).

Kaloeng traditional houses are made of local materials which people can easily obtain in the region. They use natural materials for roofing; grass (thatch) or wooden tiles. The traditional roof shape is inclined about 45 degrees. After metal sheet was introduced, roof shape was gradually changed from Type a to type b, $c, d$ or e.

Type a has a roof with an incline of over 40 degrees. Nearly a half of the studied houses have roof with an incline of 25 degrees (type b). Type $\mathrm{c}$ and $\mathrm{d}$ have the same roof incline of less than 10 degrees. Type $\mathrm{c}$ has an open space i.e. Tai-toon while type $\mathrm{d}$ has an enclosed ground floor. Type e has an eave and looks similar in appearance with modern townhouses.

\section{4-4 Spatial Formation}

Spaces are created by using partitions in the main building such as A, B, C, and D in plan (Fig. 16). Spaces are divided for bedroom, utility, living and storage. Almost half of the houses are formed as A type plan. This is the principal space formation. Basically, bedroom is arranged as open plan in type A (without any physical partition). Type B is derived from type A. When a family has grown, Suam is partitioned to a room (B1). Furthermore,

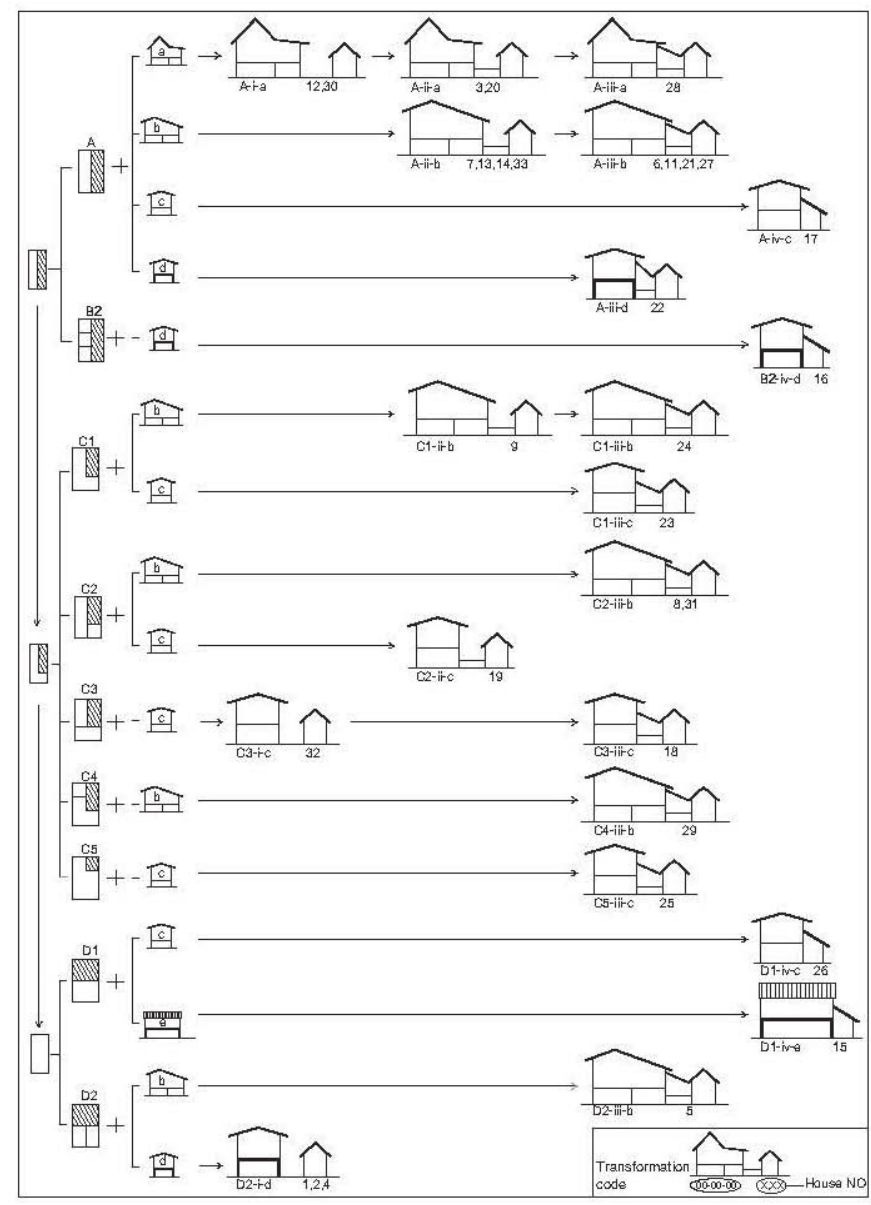

Fig. 17 Transformation process 
Bedroom can be divided into three small rooms (B2). Type C plan is also derived from Type A. Owing to wider sleeping area, there are variations of divided internal space (C1, C2, C3, C4 and C5). This type of plan is suitable for large family. Normally, after a daughter gets married they will divide Suam to be a living place for the new couple. But in case that Hong Kang does not have enough space to share, they will convert a part of Shan Nai to be a room, called Suam (house No. 8, 9, 19, 23, 24, 25, 29, 31 and 32). On the other hand, some of them are used for Pueng instead, such as house No.18. The plan of Type D includes several patterns. Four of them used partition to separate space into two rooms, such as house No. 1, 2, 4, and 5. The other two houses, No.15 and 26 have one room with semi-open terrace on the upper floor. Inhabitants noted that concrete houses were built by craftsmen outside the village. After it was introduced to the village, a concrete house is considered more fashionable by the upper class people ${ }^{20}$. The concrete house following the industrial house has spread widely in Northeastern Thailand for 30 years.

\section{Transformation of Kaloeng House}

We classify four types of houses (i, ii, iii, iv) as Fig. 13 shows. We can guess the transformation process based on the analysis of the correlations among these four types.

House is not built as a completed house at once in the beginning. It is formed gradually according the changing needs of the dwellers. In the first stage, inhabitants build Huen Noi and live in it for a few years. They later add additional spaces according to the needs of the inhabitants step by step. Once a permanent house is built, they convert Huen Noi to a kitchen. Thus, two buildings become the principal elements. Type $\mathrm{i}$ is this basic type. In the next stage, inhabitants add Shan as a linkage to the upper floor (type ii). This organization is very common. And then, the terrace is covered by a roof and walls (type iii). Type iv is different from these types above.

While the house organization transforms from i- iii \& iv, roof shape also changed from a to b, c, d, and e, case by case. Type a uses thatch and pieces of wood as roof material. As it needs funds to maintain, the materials were changed from natural ones to iron sheets. The roof shape tends to change from type a to type $\mathrm{c}$ with a slight change in roof slopes. It is obvious that the house shape is being transformed.

Figure 16 shows plan types. In the beginning, a rectangular room is built and spaces are divided as type A- Pueng, Hong Kang and Suam are arranged in one row. There is usually no partition to divide internal space. If necessary, only space for daughters is enclosed (see Huen Koei plan in Fig. 12). Type A can be changed to $B 2$ by dividing space into three rooms. Type A covers almost $48.48 \%$ (16 units) of all selected samples and found in various type of house form, except type e (for a group; A-i-a, A-ii-a and Aiii-a, for b group; A-ii-b, and A-iii-b, for c group; A-iv-c, and for d group; A-iii-d). As the numbers of family members increase, rooms are added in various ways. One of the main patterns that we can find in this village is type A. This is the transforming process of A and/or B2 to C1, C2, C3, C4 and $\mathrm{C}$. This step of change is found in house form type iii, for example $\mathrm{C} 1-$ iii-c, C2-iii-b, C3-iii-c, C4-iii-b and C5-iii-c in Fig. 17. Additionally, space is not only for sleeping, but also for other purposes. Functions such as storage and living space are packed together in the main house. There is also transformation at the third stage, when a house is enlarged from A or B to type D (D1-iv-c, D1-iv-e, D2-i-d and D2-iii-b). In this stage, while there is no more space to expand in the upper floor, space on the ground floor is selected for other functions such as shop, toilet, kitchen, storage and parking. Thus enclosed space under the floor is a further step in the house's transformation. In this step, the house is totally transformed from a steepslope-gable-roof house situated on piles or Huen Buhan to a gentle-slopegable-roof of enclosed Tai-toon house or Huen Samai-mai.

\section{Conclusion}

This paper firstly clarifies several types of Kaloeng houses based on the field survey and then analyzes the process of their transformation. The summaries are as follows.

1) Orientation takes an important role in spatial formation of Kaloeng houses. The east is believed to be sacred, while the west is thought to be inauspicious as the direction of deaths and evil spirits. Living space is utilized based on this sense of orientation. Functions that relate to men are allocated to the eastern zone while functions that relate to women are to the west. This dichotomy of space of houses reflects their hierarchical structure of society.

2) A Kaloeng house basically consists of the main house and the kitchen unit. It has several variations.

3) Organization of dwelling units is classified into four types. The basic arrangement is composed with a house and a kitchen that are both detached buildings (type i). This is extended or converted to the other three types. They are houses with terrace added between those two minimal functions (type ii), the house with a terrace converted from being semi-exterior to be interior space by adding wall and roof (type iii), and the unification of main house and kitchen unit is the last one (type iv).

4) Transformation of a house can be explained as variations of the four types mentioned above. Regardless of original design, style and period of construction, most transformation ended in type iii. Beside this, type iv is newly introduced. Fig. 17 is a diagram showing the transformation process of houses. The spatial formation that looks unstructured in the beginning can be understood as multiple layers of the ever developing housing process to meet the changing needs of the dwellers.

Beyond the space organization in planning, roof shape has also given great impact to the overall appearance of the village. The significance of this paper is to reveal this dynamics of formation and transformation of Kaloeng houses.

\section{Endnote:}

Until now, there are many assumptions about origin of Tai people. The Tai in south East Asia is believed that their primary foundation legend centers on the divine King Khun Borom. According to the myth, he is the son of the Spirit of Heaven (a possible allusion to China, the Celestial Kingdom), and was sent to rule the Tai people. The seven sons of Khun Borom, set off in seven different directions, founding the seven original Tai principalities such as Tai Dam in Muang La or Sonla in Vietnam. There is probable existence of an actual chieftain named Khun Borom, who ruled over a region called Muang Thaeng is the name of village in Vietnam which more commonly known as Dien Bien Phu. See Vittayasakpan, 1998. pp. 226-227.

${ }^{2}$ History of Mukdahan, 1997. pp. 12-20., Kromprayadamrongrayanuparb, 1962. pp. 45.

${ }^{3}$ Warankarat, 1980. pp. 2-8.

${ }^{4}$ Tai means the groups of peoples who speaking Tai. The Tai-kadai languages, also known as Kadai or Kradai, are a tonal language family found in Southeast Asia and 
southern China. The Tai or Tai-Kadai ethnicity refers collectively to the ethnic groups of southern China and Southeast Asia that speak the Tai-Kadai languages and share similar traditions and festivals. Despite never having a unified nation-state of their own, the peoples also share or historically shared a vague idea of a "Siam" nation, corrupted to Shan or Assam in some places, and most self-identify as "Tai". For details see Vittayasakpan, 1998. pp.227-228., Pankeankat, 1988. pp.47-50 and 117., Prempriratt , 1996. pp.7-14.

Heymond, 2006. pp. 1-13, 39-44

${ }^{6}$ Pankeankat, 1988. pp. 9-15., Premprirat, 1990. pp. 7-14

Linguistic, ethnological and anthropological terms, as well as international classification methods, are presently used by experts in different ways in the Southeast Asian region. Several research teams have been working for several years on ethnic groups in this region. There are still conflicts on the classification of ethnic minorities at present. The names of this ethnic group are spelled as Tai-Kaloeng, Tai Kaleun, which is recorded in documents. Some scholars classified them into sub group of Tai people. As for details, see Chazee, 1999. pp.2., Premprirat, 1997. pp.7., Pankuenkhat, 1988. pp.47-50. And some classified them as Lao the same group of Phuan. For details see 園江 満, 2006. pp.190-193. Moreover some classified them to Mon-Khmer's sub group. See M. Leber, C. Hicker, K. Musgrave, 1964.

${ }^{8}$ There are records that Tai-kaloeng was found in Sakonnakorn and its surround and their hometown was in Lan Xang (historical kingdom, Laos) before they migrated to Thailand and scattered in Sakonnakorn and Mukdahan province. For details of the origin of Tai-Kaloeng, see John F. Embee and William L, 1950. pp.78., Rachanuphab, 1923. pp.45., Yimrewat, 2001. pp.19. These records correspond to the data from interviewing of the leader of Ban-Nongnouwn that they moved in the 19th century. The reason is the great impact of the great immigration was the war of Prince Anuwong in 1826-1828. Following the war, the population in Laos was forced to migrate to reside in either Thailand or Vietnam. In Thailand they were swept to reside in the areas surrounding the Phu Phan Mountain rang (Sakonnakorn, Nakhon Panom and Mukdahan provinces). After the wars finished, some moved back to Laos and some still remained living in Mukdahan and Sakonnakorn until present. See details of the war of Prince Anuwong in Heymond, 2002 and Theerasawat, 1988.

${ }^{9}$ The surveying was conducted in the area of Sakonnakorn and Mukdahan province during the period from Jan. 1999 to Nov. 2000. Base on interviewed with Kaloeng`s community's leaders and by physical surveying in those areas founded that BanNongnouwn's physical feature is still preserved their features as they first settled. In contrast, the others have been changed. There are reasons why Ban-Nongnouwn still preserved their features as they first settled in 1887. Firstly, is the location of the village; it is quite far from downtown so the land price is lower than the others areas. Even though they sold their land, the advantage is not enough to buy new place to construct a new house. Secondary, Ban-Nongnouwn is located on the land that quite remains fertile land for cultivating for their own group's demands.

${ }^{10}$ Interview to the leader of the commune and the scholars in the village during surveying in 2000 Nov. They said that their ancestor's believed the hometown was in Muang Theng and moved to the south of Laos as Muang Wang of Savannaket in Laos. Because of the war in the 19th century, their precursors were swept to Thai and formed the village in Mukdahan and Sakonnakorn. Some villages the was mixed with other Tai groups, while some moved back to Laos, such a number of villages remain their own lifestyle as they were in hometown

1 'Don' means a slightly slope mound which is covered with forest. 'Poo ta' means the death ancestor believed as the village's protector--for peaceful and good health. Here is a place for the spiritual ritual. In case of the commune's member performed any terrible matters to someone in the village, they may be laid under a seriously awful curse so they have to admit of quilt here. This could be assumed that it is a mean to control and rule the members.

2 'Lak' means 'stay still' and 'strength' in Thai word. It is a word to call a post or pillar in Thai. A post usually made of wood, is believed to be set in the dwelling place of the guardian spirit of a village. 'Ban' means village in Thai. This post is placed in a center of the village and represented as symbol of a group of people who gathered together in one commune.

3 'Tau' means body or main part. 'Huen' means house in Northeastern Thai word. Tau-huen is a word to call main house or main building.

${ }^{14}$ Toilet and bathroom were introduced later. In the past time, people took a bath at river or Shan, and excreted outside dwelling.

15 'Huen Buhan' is an ordinary name for calling raised floor house that under the floor is an open space without partitions or barriers. Space under floor is used for multipurpose as weaving, sleeping place in day time, community with neighborhoods and for keeping pets. 'Buhan' is a word means old fashion, traditional style.

6 'Huen Noi' is a single pitched roof that is temporarily used for a new settlement and for a new family. Even though main structures are made of timber, walls and floors are still made of stripped woven bamboos. The house floor plan includes sleeping quarters and cooking area, which can be accessed through adjacent platform to the back of the house. Noi means small in Thai.

7 'Huen Koei' is a main house that is attached with a covered terrace (Koei) along the longitudinal side of the house. An open platform (Shan Nai) with verandah space called ' Koei' also runs along the same side of the house.

8 'Huen Samai-mai' is a word to call house type ground floor of which is enclosed with wall. It is used to call dwelling unit whose main materials of structure is reinforced concrete and brick. The word 'Samai-mai' means fashionable and modish.

${ }^{19}$ Some one calls this 'Pai-tin', but there is no official name for this space, which is provided as transitional space.

${ }^{20}$ The minority groups including Tai- people are sometimes are looked down in terms of their status, fashion style, lifestyle, and appearance. For this reason, quite a lot of minorities tend to modify their houses into concrete houses as their own characteristics, like cloths, fashion, language (at present, lots of minority speak Central Thai instead of their own language)

\section{Referances:}

1) Chazee, Laurent, 1999. THE PEOPLE OF LAOS; Rural and Ethnic Diversities. White Lotus Press. Bangkok.

2) Edmondson, J.A., Solnit, D.B., 1997. COMPARATIVE KADAI; the Tai branch. Summer Institute of Linguistics and the University of Texas at Arlington. Dallas.

3) Heymond, Dusadee, 2006. A SHORT HISTORAY OF LAOS; The Land in Between. OS Printing house. Bangkok. (Thai)

4) Kesornrach, Thawil, 1963. PRAWAT PHUTAI. Print place not presence. (Thai)

5) M. Leber, Frank, C. Hicker, Gerald, K. Musgrave, John, 1964, ETHNIC GROUP OF MAINLAND SOUTHEAST ASIA. Human Relations Area

6) Mansfield, Stephen, 2000. LAO HILL TRIBES; Traditions and Patterns of Existence. Oxford University Press. USA.

7) Pankheunkhat, Rengdech, 1990. PHASATHIN TRAKUL TAI. Chulalongkorn University. Bangkok. (Thai)

8) -----, 1997. PRAWAT MUKDAHAN; prachakorn lae watthanatham. Mukdahan Printed. Mukdahan. (Thai)

9) Rachanuparb, Kromprayadamrong, 1923. THIEW THI TANG TANG PARK THI SI. Soponpanthanakorn. Bangkok. (Thai)

10) Ramittanon, Charatchai, 2000. TAI, Mingmueng Printed. Chiang mai. (Thai)

11) Prempriratt, Suwilai, 1996. "Language Diagram of Tai ethnic group in Thailand," LANGUAGE AND CULTURAL STUDY JOURANL. Silpakorn University. Bangkok. Vol. 2, May, p.7- 17 (Thai)

12) Schliesinger, Joachim, 2001. TAI GROUPS IN THAILAND; Volume 2: Profile of the existing groups. White Lotus. Bangkok

13) -----, 1991. TAI-KADAI. Chulalongkorn University. Bangkok. (Thai)

14) Thammawatt, Jaruwan, 2001. TUMNAN KLOOM CHAT PHAN TAI-LAO SAMPAN RAWANG TUMNAN KAB BARIBODH TANG SANGKOM Chulalongkorn University. Bangkok. (Thai)

15) Theerasasawat, Suwit, Upat, Narong, 1996 KARN PLEIN PLENG VITHICHIWIT LAE CHUMCHON I-SAN; KORANEE PHU-TAI. Faculty of Humanities and Social Sciences. Khonkean University. (Thai)

16) Vittayasakpan, Sompong, 1998. "Thinthan khong krum chatpan tai nai punpandinyai asia tawanoakchiangtai" in TAI, Mingmuang Press. Chiang mai. pp.220-235. (Thai)

17) Warankarat, Surat, 1980. MUANGBORAN JOURANL. Vol.7, Aug-Nov, pp. 108114.(Thai)

18) W.C, Dodd, 1923. THE TAI RACE, Elder Brother of the Chinese, Torch Press. Cedar Rapids.

19) Wongthet, Sujitt, 1995. MUKDAHAN MUANG MAENAM KONG. Matichon. Bangkok. (Thai)

20) Yimrewatt, Pattiya, 2000. PRAWATSART SIPSONG JUTAI NAI VIETNAM Sangsan Printed. Bangkok. (Thai)

21) 園江 満, 2006. ラオス北部の環境と農耕技術一夕イ文化圈における稲作の生 態. 慶友社. (Japanese)

22) 田中麻里, 2006, タイの住まい. 圓津喜屋.(Japanese)

\section{和文要約}

本稿は、これまで全く明らかにされてこなかった、タイ東北部に居住するタ イカロン族の伝統的住居の空間構成とその変容を明らかにすることを目的とし ている。その住居類型を明らかにし、その比較・考察をもとに変容過程を明ら かにしたのは本稿が初めてである。タイカロン族はタイ族の一部に分類されて いるが、その集落は、現在、かつての姿を失いつつある。そうした中で、唯一 ムクダハン県にあるバン・ノンナウン村がまだ昔の形状を残している。タイカ ロン族は、本稿で述べるようにヴェトナム、ラオスの各地を通じてタイに移動 してきたことが分かっている。本研究は、各地のタイカロン族の住居集落を比 較することを大きな目的としている。タイカロン族の住居は分棟型の住居の系 列に属する。日本の二棟造りを含めた他の地域の分棟型住居との比較が大きな 視点となる。

本稿では、起源の村となる母村に焦点を当て、全 79 世帯のうち 33 世帯につ いて実測調查を行い、ヒヤリングを行った。それをもとに、まず、カロン族の 住居の基本的構成を明らかにした。一般的に、母屋（寝室のユニット）と付属 屋（㕌房ユニット）からなり、オリエンテーションを重視していることなどで ある。続いて、各棟の組合せ、屋根形状、平面構成などをもとに住居をまず大 きく 4 つに分類し、その相互関係を考察することにおいて、またヒヤリングを もとに、各類型間の関係とともに、変容過程を明らかにした。

他のタイ族や他地域（国）のカロン族の住居との比較・考察は別稿としたい。 